\title{
Uji Coba Produk Nugget Berbahan Dasar Ikan Cakalang (Katsuwonus Pelamis) dengan Penambahan Tepung Daun Kelor (Moringa Oleifera L)
}

\author{
Henry Winnarko $^{1^{*}}$, Yogiana Mulyani ${ }^{2}$ \\ ${ }^{1,2}$ Politeknik Negeri Balikpapan \\ *henry.winnarko@poltekba.ac.id
}

\begin{abstract}
Cakalang fish nuggets is a product of skipjack fish meat with dough and coating to maintain its quality. To increase the nutritional content of nuggets by adding Moringa leaf flour. The specific objectives of this study are to describe the development of skipjack-based nugget recipes by adding Moringa leaf flour, to apply skipjack tuna and Moringa leaf flour recipes, and to describe the results of sensory tests on tuna fish nugget recipes by adding Moringa leaf flour. This research was conducted at Balikpapan. This study involved 25 students majoring in Food Management as panellists. Based on the results of the hedonic test, the panellists stated that the formula 2 product with the addition of $10 \%$ Moringa flour in the production of skipjack tuna with an average value (3.97), which means panelists like it. Based on the hedonic quality test, it was concluded that the highest average results obtained in formula 3 with the addition of moringa leaf flour as much as $15 \%$ in the colour aspect (4.72) which states very green moss, in the addition of Moringa leaf flour as much as $15 \%$ in the aspect of aroma (3.96) which states scented Moringa leaves, the addition of Moringa leaf flour as much as $15 \%$ in the aspect of texture (4.04) which states solid textured, and the addition of Moringa leaf flour as much as $15 \%$ in the aspect of taste (4.20) which states savory and tastes of Moringa leaves. The suggestion for this research is the need to make labels and packaging for cakalang fish (katsuwonus pelamis) based nugget products with the addition of moringa leaf flour (moringa oleifera l) so that it can be directly marketed to the public.
\end{abstract}

Keywords: Nugget, Skipjack Fish, Moringa Leaf Flour

\begin{abstract}
Abstrak
Nugget ikan cakalang adalah produk daging ikan cakalang dengan adonan dan pelapis untuk mempertahankan kualitasnya. Untuk meningkatkan kandungan gizi nugget dengan menambahkan tepung daun kelor. Tujuan khusus penelitian ini adalah mendeskripsikan pengembangan resep nugget berbahan dasar ikan cakalang dengan penambahan tepung daun kelor, mempraktekkan resep nugget ikan cakalang dan tepung daun kelor, dan mendeskripsikan hasil uji sensori terhadap resep nugget ikan cakalang dengan penambahan tepung daun kelor. Penelitian ini menggunakan jenis penelitian kuantitatif dengan menggunakan metode eksperimental. Penelitian ini melibatkan 25 mahasiswa jurusan tata boga sebagai panelis. Hasil uji hedonik disimpulkan bahwa produk Formula 2 dengan penambahan tepung kelor 10\% pada pembuatan nugget ikan cakalang dengan nilai rata-rata (3.97) yang berarti panelis suka. Berdasarkan uji mutu hedonik, disimpulkan bahwa hasil rata-rata tertinggi yang didapatkan pada formula 3 dengan penambahan tepung daun kelor sebanyak $15 \%$ pada aspek warna (4.72) yang menyatakan sangat berwarna hijau lumut, pada penambahan tepung daun kelor sebanyak $15 \%$ pada aspek aroma (3.96) yang menyatakan beraroma daun kelor, pada penambahan tepung daun kelor sebanyak $15 \%$ pada aspek tekstur (4.04) yang menyatakan bertekstur padat, dan penambahan tepung daun kelor sebanyak $15 \%$ pada aspek rasa (4.20) yang menyatakan gurih dan berasa daun kelor. Saran untuk penelitian ini adalah perlunya pembuatan label dan kemasan untuk produk nugget berbahan dasar ikan cakalang (katsuwonus pelamis) dengan penambahan tepung daun kelor (moringa oleifera l) sehingga dapat langsung dipasarkan kepada masyarakat .
\end{abstract}

Kata Kunci: Nugget, Ikan Cakalang, Tepung Daun Kelor

\section{Pendahuluan}

Ikan merupakan pangan hewani yang memiliki beberapa keunggulan dibandingkan sumber protein lainnya, diantaranya kandungan protein yang cukup tinggi dengan susunan asam amino yang berpola mendekati kebutuhan asam amino dalam tubuh manusia. Daging ikan juga mengandung asam lemak tak jenuh yang dibutuhkan oleh tubuh manusia 
(Adawiyah, 2007). Salah satu contohnya adalah ikan cakalang yang mempunyai kandungan gizi yang baik untuk kesehatan tubuh. Ikan cakalang (katsuwonus pelamis) memiliki kandungan omega 3 yang sangat tinggi. Omega 3 ini merupakan lemak esensial yang dapat mendukung daya ingat otak. Oleh karena itulah, omega 3 sering dikonsumsi oleh anak-anak sebagai bentuk suplemen untuk membantu menjaga kesehatan mata dan kulit, sirkulasi jantung, pembekuan darah dan kuat tulang. Serta dapat melindungi tubuh dari berbagai penyakit, seperti Kanker Pankreas, Ovarium, Mulut, Faring, Lambung, Kerongkongan serta Usus Besar (Wulandari,2014).

Ikan cakalang (katsuwonus pelamis) terdapat hampir di seluruh perairan Indonesia, terutama di Manado dan Maluku, merupakan salah satu pusat kegiatan penangkapan cakalang di Indonesia (Hutabarat, 2016). Berdasarkan hasil observasi lapangan, ikan cakalang memiliki produksi dengan rata-rata penjualan $20 \mathrm{~kg} / \mathrm{hari}$ di beberapa pasar-pasar di kota Balikpapan. Hal ini menandakan bahwa bahan baku sangat mudah di temukan di kota Balikpapan. Selama ini, masyarakat memiliki keterbatasan pengetahuan dalam upaya diversifikasi olahan ikan cakalang menjadi olahan yang memiliki added value. Karena sebagian masyarakat hanya mengetahui metode mengolah ikan cakalang (katsuwonus pelamis) hanya dengan di goreng, sebagai isian dari panada, dijadikan ikan asap, dan menjadi abon ikan cakalang. Untuk itu diperlukan peningkatan pengetahuan pengolahan makanan yang berbahan dasar ikan cakalang guna memberikan alternatif pilihan dan untuk meningkatkan konsumsi ikan pada anak-anak, salah satu olahan makanan yang digemari oleh masyarakat adalah nugget.

Nugget adalah produk daging dengan adonan dan pelapis untuk mempertahankan kualitasnya. Nugget sangat digemari oleh kalangan masyarakat. Nugget yang dijual dipasaran juga sudah sangat banyak, dengan merek yang berbeda-beda (Rohaya, Husna dan Bariah, 2013). Menurut Afrianto dan Evi (1989) nugget terbuat dari gilingan daging dengan beberapa bahan penambah seperti tepung terigu, bumbu, telur dan lain-lain yang digulir dalam tepung panir. Untuk meningkatkan kandungan gizi nugget diperlukan penambahan sayuran yang memiliki serat dan vitamin yang lengkap, salah satu contoh sayuran tersebut adalah tanaman kelor (moringa oleifera).

Tanaman kelor (moringa oleifera) merupakan salah satu jenis tanaman tropis yang mudah tumbuh di daerah tropis seperti Indonesia. Tanaman kelor merupakan tanaman perdu dengan ketinggian 7-11 meter dan tumbuh subur mulai dari dataran rendah 0 sampai ketinggian 700 meter di atas permukaan laut. Kelor dapat tumbuh pada daerah tropis dan subtropis pada semua jenis tanah dan tahan terhadap musim kering dengan toleransi terhadap kekeringan sampai 6 bulan (Mendieta-Araica at al., 2013). Kelor dikenal diseluruh dunia sebagai tanaman bergizi dan World Health Organization (WHO) telah memperkenalkan kelor sebagai salah satu pangan alternative untuk mengatasi masalah gizi (malnutrisi) (Broin, 2010). Berbagai bagian dari tanaman kelor seperti daun, akar, biji, kulit kayu, buah dan bunga bertindak sebagai stimulan jantung dan peredaran darah, memiliki anti tumor, anti hipertensi, menurunkan kolesterol, antioksidan, anti diabetik, anti bakteri dan anti ikan (Krisnadi, 2015).

Penelitian lain menyatakan bahwa daun kelor mengandung vitamin A 10 kali lebih banyak dibanding wortel, vitamin B 50 kali lebih banyak dibanding sardines dan kacang, vitamin E 4 kali lebih banyak dibanding minyak jagung, beta karoten 4 kali lebih banyak dibanding wortel, zat besi 25 kali lebih banyak dibanding bayam, zinc 6 kali lebih banyak dibanding almond, kalium 15 kali lebih banyak dibanding pisang, kalsium 17 kali lebih banyak dibanding susu, dan protein 9 kali lebih banyak dibanding yoghurt (Krisnadi, 2015).

Berdasarkan uraian diatas, maka tujuan dari penelitian ini adalah untuk mengembangkan resep nugget berbahan dasar ikan cakalang dengan penambahan tepung daun kelor serta meningkatkan ketahanan pangan masyarakat sekitar, mempraktekkan resep nugget ikan cakalang dan tepung daun kelor, dan mendeskripsikan hasil uji sensori terhadap resep nugget ikan cakalang dengan penambahan tepung daun kelor. 


\section{Metodologi}

Jenis penelitian ini adalah jenis penelitian kuantitatif dengan menggunakan metode eksperimental. Penelitian ini dilakukan di Balikpapan yang berlangsung dari bulan AprilDesember 2019. Dalam penelitian ini populasi pendahuluan yang digunakan adalah Ikan Cakalang (katsuwonus pelamis) dan tepung daun kelor yang ada di Pasar kota Balikpapan. Panelis dalam penelitian ini adalah 25 mahasiswa jurusan Tata Boga di Balikpapan. Pengambilan sampel dilakukan dengan sistem random sampling. Teknik analisis data dalam penelitian ini yaitu menggunakan analisis statistik deskriptif dan dan analisa kuantitatif dengan menggunakan program SPSS 25.0 ForWindows.

Adapun tahapan prosedur penelitian yang telah dilakukan dapat dilihat pada gambar 1 dibawah ini:

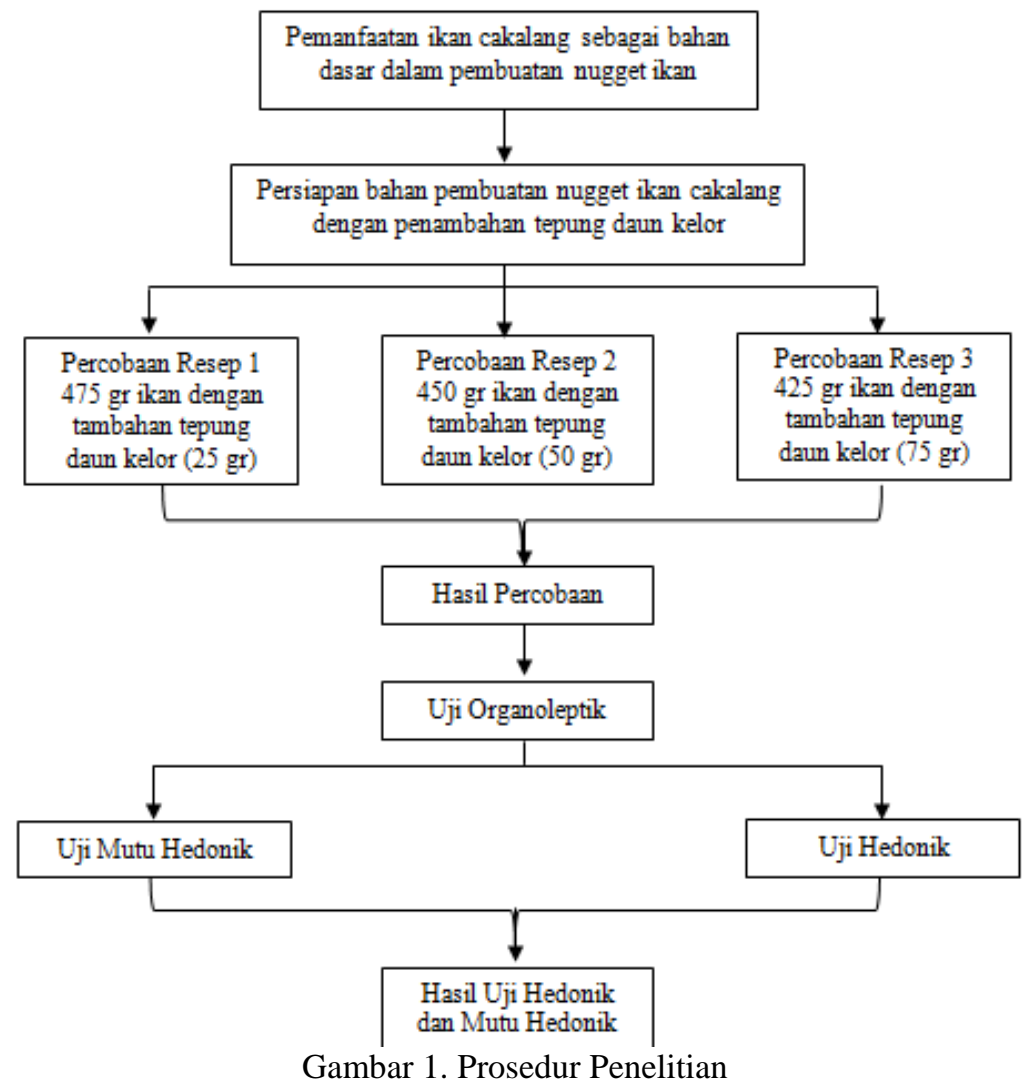

\section{Hasil dan Pembahasan \\ Pembuatan Nugget}

Proses pembuatan nugget ikan cakalang dengan penambahan tepung daun kelor yaitu dengan penambahan tepung daun kelor sebanyak 5\% pada formula $1,10 \%$ pada formula 2 dan $15 \%$ pada formula 3 . Untuk membuat nugget ikan cakalang dengan penambahan tepung daun kelor sebelumnya melalui beberapa tahap untuk mendapatkan resep standar. Kemudian resep standar tersebut diformulasikan menjadi tiga formulasi dimana formula 1 dengan penggunaan 95\% daging ikan cakalang dan 5\% tepung daun kelor, formula 2 dengan penggunaan $90 \%$ daging ikan cakalang dan $10 \%$ tepung daun kelor, dan formula 3 dengan penggunaan $85 \%$ daging ikan cakalang dan $15 \%$ tepung daun kelor. Tahap pertama yaitu mulai dari persiapan alat dan bahan yang digunakan dalam pembuatan, mencampur bahan kedalam wadah, memasukkan adonan kedalam cetakkan, mengukus nugget, memotong dan membentuk nugget ikan cakalang, memaniri nugget. Selanjutnya nugget digoreng selama \pm 7 menit dengan menggunakan metode deep frying. Tahap akhir, nugget disajikan dan disebarkan kepada panelis. Hasil produk nugget dapat dilihat di bawah ini. 


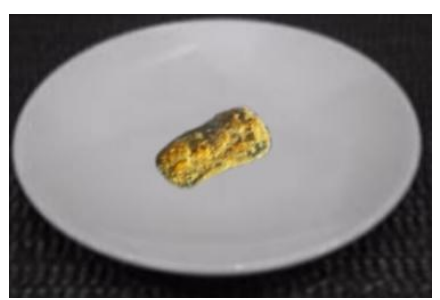

Gambar 2. Hasil Nugget Ikan Cakalang (formula 1) dengan Penambahan Tepung Daun Kelor Sebanyak 5\%

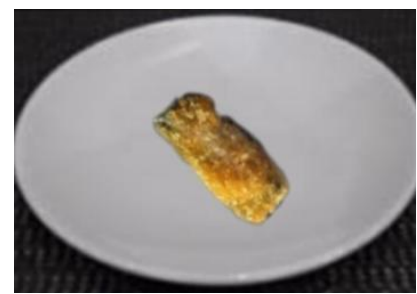

Gambar 3. Hasil Nugget Ikan Cakalang (formula 2) dengan Penambahan Tepung Daun Kelor Sebanyak 10\%

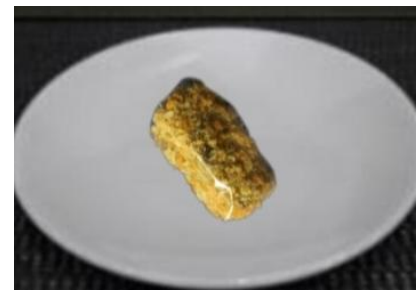

Gambar 4. Hasil Nugget Ikan Cakalang (formula 3) dengan Penambahan Tepung Daun Kelor Sebanyak 15\%

Setelah menemukan resep acuan yang sesuai penulis membuat produk dan angket yang dilakukan pada tanggal 2 Agustus 2019 kepada mahasiswa tata boga semester 3 sebanyak 25 panelis agak terlatih di Balikpapan. Langkah-langkah yang dilakukan penulis adalah meyebarkan produk dan angket, lalu memberikan pengarahan tentang bagaimana cara mengisi lembar angket, terdapat dua lembar angket untuk setiap panelis. Lembar pertama merupakan uji hedonik dan lembar kedua adalah uji mutu hedonik. Setelah data diperoleh kemudian diolah dengan menggunakan SPSS 25 for windows data tersebut untuk mengetahui tingkat kesukaan dan mutu produk nugget ikan cakalang dengan penambahan tepung daun kelor dari aspek warna, aroma, tekstur dan rasa.

\section{Pengujian Hedonik (Kesukaan)}

Hasil nilai rata-rata pengujian kesukaan penelis terhadap nugget ikan cakalang dengan penambahan tepung daun kelor dapat dilihat pada tabel 1 dibawah ini:

Tabel 1. Hasil Rata-Rata Uji Hedonik Nugget Ikan Cakalang Dengan Penambahan Tepung Daun Kelor

\begin{tabular}{ccccc}
\hline \multirow{2}{*}{ No } & \multirow{2}{*}{ Spesifikasi } & \multicolumn{3}{c}{ Kode Sampel } \\
\cline { 3 - 5 } & & Formula 1 & Formula 2 & Formula 3 \\
\hline 1. & Warna & 3,8 & 3,6 & 3,72 \\
\hline 2. & Aroma & 4,16 & 4,16 & 3,84 \\
\hline 3. & Tekstur & 3,88 & 3,96 & 3,96 \\
\hline 4. & Rasa & 3,64 & 4,16 & 3,72 \\
\hline
\end{tabular}

\section{Warna}

Tiap nugget ikan cakalang memiliki perbedaan hasil pada warna yaitu pada nugget ikan cakalang dengan penambahan tepung daun kelor sebanyak 5\% memiliki warna agak 
hijau lumut, pada nugget ikan cakalang dengan penambahan tepung daun kelor sebanyak $10 \%$ memiliki warna hijau lumut dan pada nugget ikan cakalang dengan penambahan tepung daun kelor sebanyak 15\% memiliki warna sangat hijau lumut. Berdasarkan hasil uji hedonik formula 1 pada aspek warna panelis menyatakan suka dengan nilai rata-rata (3.80), untuk formula 2 panelis menyatakan suka dengan nilai $(3,60)$ dan untuk formula 3 panelis menyatakan suka dengan nilai $(3,72)$. Nilai rata-rata tertinggi dari ketiga produk pada aspek warna, yaitu produk formula 1.

\section{Aroma}

Untuk perbedaan hasil pada aroma yaitu pada nugget ikan cakalang dengan penambahan tepung daun kelor sebanyak 5\% agak beraroma daun kelor, pada nugget ikan cakalang dengan penambahan tepung daun kelor sebanyak $10 \%$ beraroma daun kelor dan pada nugget ikan cakalang dengan penambahan tepung daun kelor sebanyak $15 \%$ sangat beraroma daun kelor. Berdasarkan hasil uji hedonik formula 1 pada aspek aroma panelis menyatakan suka dengan nilai rata-rata $(4,16)$, untuk formula 2 panelis menyatakan suka dengan nilai $(4,16)$ dan untuk formula 3 panelis menyatakan suka dengan nilai $(3,84)$. Nilai rata-rata tertinggi dari ketiga produk pada aspek aroma, yaitu produk formula 1 dan formula 2.

\section{Tekstur}

Untuk tekstur tidak berbeda jauh pada setiap formula, yaitu memiliki tekstur yang padat. Berdasarkan hasil uji hedonik formula 1 pada aspek tekstur panelis menyatakan suka dengan nilai rata-rata $(3,88)$, untuk formula 2 panelis menyatakan suka dengan nilai $(3,96)$ dan untuk formula 3 panelis menyatakan suka dengan nilai $(3,96)$. Nilai rata-rata tertinggi dari ketiga produk pada aspek tekstur, yaitu produk formula 2 dan formula 3.

\section{Rasa}

Untuk perbedaan hasil pada rasa, yaitu nugget ikan cakalang dengan penambahan tepung daun kelor sebanyak 5\% memiliki rasa gurih dan agak terasa daun kelor, pada nugget ikan cakalang dengan penambahan tepung daun kelor sebanyak $10 \%$ memiliki rasa gurih dan terasa daun kelor serta pada nugget ikan cakalang dengan penambahan tepung daun kelor sebanyak $15 \%$ memiliki rasa gurih dan sangat terasa daun kelor. Berdasarkan hasil uji hedonik formula 1 pada aspek rasa panelis menyatakan suka dengan nilai rata-rata $(3,64)$, untuk formula 2 panelis menyatakan suka dengan nilai (4.16) dan untuk formula 3 panelis menyatakan suka dengan nilai $(3,72)$. Nilai rata-rata tertinggi dari ketiga produk pada aspek rasa, yaitu produk formula 2.

Tabel 1 memperlihatkan bahwa secara keseluruhan uji hedonik yang paling disukai panelis adalah formula 2. Penambahan tepung daun kelor 10\% (formula 2) pada nugget ikan cakalang menghasilkan aroma, tekstur, rasa yang lebih disukai oleh panelis kecuali warna. Warna nugget ikan cakalang dengan penambahan tepung daun kelor 5\% lebih disukai karena warna yang dihasilkan cukup berwarna kehijauan lumut.

\section{Pengujian Mutu Hedonik}

Hasil nilai rata-rata pengujian mutu hedonik penelis terhadap nugget ikan cakalang dengan penambahan tepung daun kelor dapat dilihat pada tabel 2 dibawah ini. 
Tabel 2. Hasil Rata-Rata Uji Mutu Hedonik Nugget Ikan Cakalang Dengan Penambahan Tepung Daun Kelor

\begin{tabular}{ccccc}
\hline \multirow{2}{*}{ No } & \multirow{2}{*}{ Spesifikasi } & \multicolumn{3}{c}{ Kode Sampel } \\
\cline { 3 - 5 } & & Formula 1 & Formula 2 & Formula 3 \\
\hline 1. & Warna & 3,56 & 4,08 & 4,72 \\
\hline 2. & Aroma & 3,2 & 3,76 & 3,96 \\
\hline 3. & Tekstur & 3,4 & 3,72 & 4,04 \\
\hline 4. & Rasa & 3,52 & 3,92 & 4,20 \\
\hline
\end{tabular}

Keterangan:

Formula 1 : Nugget ikan cakalang dengan penambahan tepung daun kelor $5 \%$

Formula 2 : Nugget ikan cakalang dengan penambahan tepung daun kelor $10 \%$

Formula 3 : Nugget ikan cakalang dengan penambahan tepung daun kelor $15 \%$

\section{Warna}

Berdasarkan hasil uji mutu hedonik formula 1 pada aspek warna panelis menyatakan berwarna hijau lumut dengan nilai rata-rata $(3,56)$, untuk formula 2 panelis menyatakan hijau lumut dengan nilai $(4,08)$ dan untuk formula 3 panelis menyatakan sangat hijau lumut dengan nilai $(4,72)$. Hal ini karena perbedaan pada penambahan tepung daun kelor sehingga warna yang dihasilkan berbeda. Nilai rata-rata tertinggi dari ketiga produk pada aspek warna, yaitu produk formula 3. Hal ini didukung oleh penelitian Widyawatiningrum dkk, (2018) yang menyatakan bahwa semakin banyak penambahan daun kelor yang dicampurkan ke dalam adonan nugget ayam, maka warna produk nugget ayam akan semakin hijau. Warna hijau ini disebabkan daun kelor banyak mengandung klorofil dengan konsentrasi yang tinggi yaitu $6890 \mathrm{mg} / \mathrm{kg}$ bahan kering. Hal ini sesuai dengan kandungan daun kelor yang memiliki 4x lebih banyak dibandingkan dengan wheatgrass (Kurniasih, 2015).

\section{Aroma}

Berdasarkan hasil uji mutu hedonik formula 1 pada aspek aroma panelis menyatakan agak beraroma daun kelor nilai rata-rata $(3,20)$, untuk formula 2 panelis menyatakan beraroma daun kelor dengan nilai $(3,76)$ dan untuk formula 3 menyatakan beraroma daun kelor dengan nilai $(3,96)$. Hal ini karena perbedaan pada penambahan tepung daun kelor sehingga aroma yang dihasilkan berbeda. Nilai rata-rata tertinggi dari ketiga produk pada aspek aroma, yaitu produk formula 3. Nugget yang diberikan kepada panelis adalah nugget yang telah digoreng. Aroma yang dihasilkan oleh nugget berasal dari bahan utama yaitu ikan cakalang dan daun kelor. Hal ini didukung oleh Winarno, (2004) yang menyatakan bahwa hal yang mempengaruhi cita rasa bahan pangan terdiri dari 3 komponen yaitu bau, rangsangan mulut dan rasa.

\section{Tekstur}

Berdasarkan hasil uji mutu hedonik formula 1 pada aspek tekstur panelis menyatakan agak padat dengan nilai rata-rata $(3,40)$, untuk formula 2 panelis menyatakan padat dengan nilai $(3,72)$ dan untuk formula 3 panelis menyatakan padat dengan nilai $(4,04)$. Hal ini disebabkan komposisi tepung, roti dan telur oleh pembuatan nugget ikan cakalang. Nilai rata-rata tertinggi dari ketiga produk pada aspek tekstur, yaitu produk formula 3. Semakin banyak tepung yang ditambahkan kedalam campuran adonan maka adonan akan semakin padat, sebaliknya jika kadar air dalam adonan semakin banyak maka tekstur yang dihasilkan pada nugget akan semakin lembek (Widyawatiningrum dkk, 2018). 


\section{Rasa}

Berdasarkan hasil uji mutu hedonik formula 1 pada aspek rasa panelis menyatakan gurih dan berasa daun kelor dengan nilai rata-rata $(3,52)$, untuk formula 2 panelis menyatakan gurih dan berasa daun kelor dengan nilai $(3,92)$ dan untuk formula 3 panelis menyatakan gurih dan berasa daun kelor suka dengan nilai $(4,20)$. Hal yang menyebabkan panelis menyatakan gurih dan berasa daun kelor pada produk formula 3 karena takaran daun kelor yang lebih banyak. Nilai rata-rata tertinggi dari ketiga produk pada aspek rasa, yaitu produk formula 3. Semakin banyak penambahan daun kelor maka rasa yang didapatkan semakin berasa daun kelor. Hal ini dikarenakan pada daun kelor mengandung lebih banyak air dibandingkan daging ikan cakalang. Variasi presentase penggunaan daging ikan cakalang sebagai bahan utama pembuatan nugget tidak mempengaruhi tingkat kesukaan terhadap rasa nugget. Hal ini dikarenakan penambahan komposisi bumbu dan bahan pembantu yang dimasukkan menggunakan takaran yang sama sehingga menghasilkan rasa nugget yang sama.

Tabel 2 memperlihatkan bahwa hasil dari keseluruhan uji mutu hedonik yang dipilih oleh panelis adalah formula 3. Penambahan tepung daun kelor $15 \%$ (formula 3) pada nugget ikan cakalang menghasilkan warna, aroma, tekstur, dan rasa yang lebih dipilih oleh panelis. Formulasi yang terbaik adalah formula 3 yang menghasilkan nugget ikan cakalang dengan penambahan tepung daun kelor. Warna formula 3 pada nugget ikan cakalang dengan penambahan daun kelor memiliki warna hijau yang lebih menarik dibandingkan formula 1 dan formula 2. Hal ini didukung oleh Muchtadi, dkk (2011) yang menyatakan bahwa sayuran hijau mengandung pigmen klorofil yang banyak, sifat non polar klorofil yang tidak larut dalam air tetapi larut dalam pelarut organik. Aroma tepung daun kelor berpengaruh terhadap aroma nugget yang disebabkan oleh kelor yang memiliki enzim lipoksidasea yang memiliki aroma khas yang tajam (Krisnadi, 2015). Penambahan jumlah tepung daun kelor akan berpengaruh terhadap rasa dari nugget ikan cakalang yang disebabkan kelor mengandung tannin (muchtadi, dkk., 2011). Tekstur nugget ikan calakang memiliki kandungan serat 5 kali lebih banyak karena adanya penambahan tepung daun kelor (krisnadi, 2015).

\section{Kesimpulan}

Proses pembuatan nugget ikan cakalang dengan penambahan tepung daun kelor yaitu Tahap pertama yaitu mulai dari persiapan alat dan bahan yang digunakan dalam pembuatan, mencampur bahan kedalam wadah, memasukkan adonan kedalam cetakkan, mengukus nugget, memotong dan membentuk nugget ikan cakalang, memaniri nugget. Selanjutnya pasta digoreng selama \pm 7 menit dengan menggunakan metode deep frying. Tahap akhir, nugget disajikan dan disebarkan kepada panelis. Berdasarkan pada hasil uji hedonik oleh panelis menyatakan bahwa produk formula 2 dengan penambahan tepung kelor $10 \%$ pada pembuatan nugget ikan cakalang dengan nilai rata-rata $(3,97)$ yang berarti panelis suka. Berdasarkan uji mutu hedonik, disimpulkan bahwa hasil rata-rata tertinggi yang didapatkan pada penambahan tepung daun kelor sebanyak $15 \%$ pada formula 3 meliputi aspek warna $(4,72)$ yang menyatakan sangat berwarna hijau lumut, pada penambahan tepung daun kelor sebanyak $15 \%$ pada aspek aroma $(3,96)$ yang menyatakan beraroma daun kelor, pada penambahan tepung daun kelor sebanyak $15 \%$ pada aspek tekstur $(4,04)$ yang menyatakan bertekstur padat ,dan penambahan tepung daun kelor sebanyak $15 \%$ pada aspek rasa $(4,20)$ yang menyatakan gurih dan berasa daun kelor. Hasil uji hedonik menunjukkan bahwa formula 2 lebih baik dibandingkan dengan formula 1 dan formula 3 sedangkan hasil uji mutu hedonik menunjukkan bahwa formula 3 lebih baik dibandingkan formula 1 dan formula 2 . 


\section{Saran}

Diperlukan adanya pembuatan label dan kemasan untuk produk nugget berbahan dasar ikan cakalang (katsuwonus pelamis) dengan penambahan tepung daun kelor (moringa oleiferal) sehingga dapat langsung dipasarkan kepada masyarakat .

\section{Ucapan Terimakasih}

Penelitian ini didanai oleh DIPA Poltekba Tahun Anggaran 2019 dengan nomor kontrak : 24/PL32.13/SPK-LT/2019.

\section{Daftar Pustaka}

Adawiyah, R. (2007). Ikan Sebagai Sumber Hewani, Jurnal Pengolahan dan pengawetan ikan, Vol. 7, No. 4 : Hal. 54-55.

Afrianto,E. dan Evi Liviawaty. 1989. Pengawetan dan Pengolahan Ikan. Yogyakarta: Penerbit Kanisius.

Broin. (2010). Growing and processing moringa leaves. France: Imprimerie Horizon.

Hutabarat, B. (2016). Subsetor perikanan dan kehandalan ekspor tuna/cakalang di Sulawesi Utara, Jurnal Data Perikanan Sulawesi Utara, vol. 2. no. 5 : Hal. 13.

Krisnadi, A.D. (2015). Kelor Super Nutrisi. Blora: LSM-MEPELING.

Kurniasih. (2015). Khasiat dan Manfaat Daun Kelor Untuk Penyembuhan Berbagai Penyakit. Yogya: Pustaka Baru Press.

Mendieta-Araica B, Spörndly E, Reyes- Sánchez N, Salmerón-Miranda F, Halling M (2013). Biomass production and chemical composition of Moringa oleifera under different planting densities and levels of nitrogen fertilization. Agroforest. Syst. 87:81-92.

Muchtadi, d. (2011). Ilmu Pengetahuan Bahan Makanan. Bandung: Alfabeta.

Rohaya, S., Husna, N.E dan Bariah. K. (2013). Penggunaan Bahan Pengisi Terhadap Mutu Nugget Vegetarian Berbahan Dasar Tahu dan Tempe. Universitas Syiah Kuala: Banda Aceh.

Widyawatiningrum, E., Nur, S., Ida,N.C. (2018). Kadar Protein dan Organoleptik Nugget Ayam Fortifikasi Daun Kelor (Moringa Oleifera Lamk). Seminar Nasional Hasil Penelitian dan Pengabdian Masyarakat 2018.

Wulandari, N. (2014). Hubungan Asupan Makanan Asam Lemak Omega 3, 6. Dilihat pada tanggal 1 April 2018, dari webcache.googleusercontent.com/search?q=cache:WwM17xLyP0QJ:media.neliti.com/media/pub lications/192808-ID 